\title{
Integrasi Program Sadar Wisata Dalam Membangun Kesadaran Literasi Di Desa Nglanggeran
}

\author{
RB. Suharta \\ Universitas Negeri Yogyakarta \\ robertus_bs@uny.ac.id \\ Erma Kusumawardani \\ Universitas Negeri Yogyakarta \\ ermakusumawardani@uny.ac.id \\ Yudan Hermawan \\ Universitas Negeri Yogyakarta \\ yudan_hermawan@uny.ac.id
}

\begin{abstract}
Abstrak
Era disrupsi ini Indonesia tidak hanya mengalami krisis ekonomi, namun juga krisis literasi. Fakta ini didasarkan pada riset Central Connecticut State University 2016, yang mengatakan bahwa literasi Indonesia berada di tingkat kedua terbawah dari 61 negara. Berdasarkan hal tersebut, kegiatan ini bertujuan membangun kesadaran literasi masyarakat melalui keterpaduan program kelompok sadar wisata dan organisasi karangtaruna. Untuk dapat membuat deskripsi, gambaran, atau lukisan secara sistematis, faktual dan akurat mengenai fakta-fakta, sifat-sifat serta hubungan antarfenomena yang di amati, maka peneliti menggunakan pendekatan kualitatif. Sehingga kegiatan sarasehan dan pendampingan sebagai satu bentuk aktivitas dalam pengumpulan data kepada masyarakat yang kemudian di analisis interaktif sesuai dengan metode deskriptif kualitatif yang kemudian menghasilkan pembentukan (1) Rintisan kemitraan antara kelompok sadar wisata dan generasi muda yang tergabung dalam organisasi karang taruna agar secara langsung terlibat dalam mengembangkan edukasi wisata. (2) Kelompok sadar wisata dalam membangun kesadaran literasi masyarakat bersama dengan Taman Bacaan Masyarakat merupakan kolaborasi yang saling menguatkan. (3) Gerakan masyarakat dalam bentuk tulisan-tulisan penyemangat akan nilai keindahan, kebersihan, ramah, etika yang diletakkan di sudut-sudut jalan serta pengadaan buku informatif tentang geopark Nglenggeran di beberapa omah (homestay) merupakan gagasan yang layak didukung oleh pemerintah setempat. Membangun kesadaran literasi bagi seluruh masyarakat menjadi penting terutama dalam mensikapi berkembangnya desa wisata dengan potensi alam yang begitu mempesona wisatawan. Untuk itulah kolaborasi kelompok sadar wisata dengan program pengembangan yang didukung taman bacaan masyarakat yang memenuhi kebutuhan belajar masyarakat kaitannya dengan gerakan mendukung desa wisata.
\end{abstract}

Kata Kunci: literasi, model integrasi, kelompok sadar wisata

\begin{abstract}
In this era of disruption, Indonesia is not only experiencing an economic crisis, but also a literacy crisis. This fact is based on a 2016 Central Connecticut State University research, which states that Indonesian literacy is in the second lowest level of 61 countries. Based on this, this activity aims to build awareness of community literacy through integrated tourism awareness group programs and youth organizations. To be able to make a systematic, factual and accurate description, description or painting of the facts, properties and relationships between observed phenomena, the researcher uses a qualitative approach. So that the workshop and mentoring activities as a form of activity in collecting data to the community are then analyzed in accordance with the qualitative descriptive method which then results in the formation of (1) Pioneering partnerships between tourism awareness groups and the young generation who are members of the youth organization to be directly involved in developing tourism education. (2) The tourism awareness group in building community literacy awareness together with
\end{abstract}


Community Reading Gardens is a mutually reinforcing collaboration. (3) Community movements in the form of encouraging writings on the values of beauty, cleanliness, friendliness, ethics placed on street corners and the procurement of informative books about the Nglenggeran geopark in several homestays are ideas that deserve to be supported by the local government. Building literacy awareness for the entire community is important, especially in response to the development of tourist villages with natural potential that fascinates tourists. For this reason, the collaboration of tourism awareness groups with development programs supported by community reading gardens that meet the learning needs of the community in relation to the movement to support tourism villages

Keywords: literacy, integration model, tourism awareness groups

\section{PENDAHULUAN}

Kehidupan saat ini memang jauh lebih cepat, praktis, dan terbuka. Era global merupakan era yang harus dihadapi oleh berbagai negara, tak terkecuali Indonesia. Tahun 2020-2030 Indonesia diprediksi akan mendapatkan bonus demografi di mana penduduk usia produktif sangat besar. Di rentang tahun tersebut diprediksi penduduk usia produktif yang sangat besar memberi dampak perekonomian yang menguntungkan. Usia produktif secara normatif dalam kondisi beraktivitas ekonomi, menggeliatkan perekonomian terutama dalam bisnis yang berbasis online, kuliner, wisata alam, pelayanan atau jasa seperti homestay. The UNWTO and UNDP (2017) menyatakan bahwa hal ini focus pada tujuan SDG yang pertama Tourism provides income through job creation at local and community levels. It can be linked with national poverty reduction strategies and entrepreneurship. Low skills requirement and local recruitment can empower less favoured groups, particularly youth and women. Selain itu, hasil penelitian lain juga memperkuat bahwa the option of a more progressive tax system is not raised and neither are issue of the tax avoidance and minimisation strategies of many large corporations with significant interests in travel and tourism (Bryan, Rafferty, \& Wigan, 2017; Schneider, 2018). Pengelolaan usaha ekonomi dengan mengandalkan potensi alam seperti pengembangan desa ekowisata saat ini menjadi trend seperti halnya di desa Nglanggeran dengan layanan panjat tebing, mendaki gunung purba atau sekedar menikmati indahnya pemandangan.

Pengembangan wilayah yang memiliki potensi alam, lingkungan merupakan asset unggulan program pemerintah yaitu pariwisata, sebagai salah satu prioritas pembangunan. Pengembangan wilayah dengan potensi wisata di seluruh Indonesia sangat memerlukan dukungan kemudahan akses dan insfrastruktur pendukung konektivitas. Upaya-upaya tersebut juga perlu diperkuat oleh dukungan masyarakat bahkan dari berbagai sektor terkait seperti pendidikan, usaha perekonomian, industri, ketahanan energi, ketahanan pangan, serta teknologi. Practically, we must position tourism into a structural management of a mobilities perspective. When potentially millions of people are going to be forced to move as political, economic and environmental refugees, justifying the facilitation of movement of pleasure-seeking tourists without accounting for their environmental and other impacts will become untenable (Higgins-Desbiolles, 2018). Sustainability itself is strongly positioned as an economic or competitive value rather than an ethical or environmental one: "many companies already seem to acknowledge that their contribution [to the SDGs] should be integrated into core business and form an inherent part of the creation of value to succeed on today's markets" (UNWTO \& UNDP, 2017). Masyarakat sebagai pendukung 
pariwisata juga perlu dipersiapkan agar sadar terhadap potensi wisata ini. "Sadar Wisata", istilah yang sering kita dengar dimaksud sebagai partisipasi dan dukungan segenap komponen masyarakat dalam mendorong terwujudnya iklim yang kondusif bagi tumbuh dan berkembangnya kepariwisataan di suatu wilayah dan bertujuan untuk meningkatkan kesejahteraan rakyat.

Pengembangan wisata pedesaan yang berbasis pengembangan potensi alam, pertanian, sosial dan budaya lokal dapat menjadi pengembangan potensi masyarakat berbasis pariwisata. Pengembangan masyarakat sebagai tempat wisata dapat mengikutsertakan peran dan partisipasi masyarakat pedesaan (Dhanik Nor Palupi Rorah, 2012). Hal ini sejalan dengan pengembangan sumber daya alam dan sumber daya manusia yang dimilikinya. Hal yang harus menjadi perhatian dalam pengembangan desa wisata yakni bagaimana masyarakat bisa didorong dan dikembangkan secara berkesinambungan dalam menunjang desa wisata. Dengan demikian potensi yang dimiliki desa dam masyarakat dapat dikembangkan secara optimal. Upaya menggali potensi desa dan masyarakat secara berkesinambungan bagi pengembangan desa wisata dapat berdampak maksimal bagi kesejahteraan masyarakat.

Beberapa tahun ini Kabupaten Gunung Kidul yang pada dasarnya memiliki tipologi geografis berupa perbukitan batu kapur, sungai, goa atau karst yang didukung keunikan sosial budaya sebagai instrumen penting untuk membangun hingga saat ini. Organisasi kesenian sebagai budaya yang terus dipupuk dan dilestarikan oleh masyarakat berjumlah 1.878 organisasi, dengan tokoh pemangku adat berjumlah 144 orang. Sementara itu desa budaya yang dikembangkan oleh pemerintah untuk menunjang kesejahteraan masyarakat sebanyak 10 desa budaya, cagar budaya yang dimiliki sebanyak 5 buah serta benda cagar budaya sejumlah 692 buah yang tersebar di wilayah Kabupaten Gunungkidul (Badan Pusat Statistik, 2018).

Salah satu obyek wisata di Kabupaten Gunung Kidul yang banyak dikunjungi wisatawan karena keunikannya adalah Gunung Api Purba yang terletak di Desa Nglanggeran Kecamatan Patuk pada ketinggian 200-700 m dpl dengan jarak tempuh $22 \mathrm{~km}$ dari kota Wonosari melalui perjalanan darat. Adapun Litologi lokasi ini tersusun oleh material vulkanik tua dan bentang alamnya memiliki keindahan yang secara geologi sangat unik dan bernilai ilmiah tinggi. Dari hasil penelitian dan referensi yang ada, dinyatakan gunung Nglanggeran adalah gunung berapi purba. Pada tahun 2007 berkembang ide kreatif para pemuda Desa Nglanggeran yang mulai membenahi dan menata lokasi ekowisata Gunung Api Purba Nglanggeran secara swadaya dengan membangun jalur pendakian, fasilitas MCK (Mandi, Cuci, Kakus), serta gubuk-gubuk peristirahatan pendakian. Pada saat mengembangkan lokasi tersebut para pemuda ini membuat wadah organisasi yang bernama Pokdarwis (kelompok sadar wisata) yang terdiri dari unsur Karang Taruna Bukit Putra Mandiri, Pemerintah Desa, kelompok tani, ibu-ibu PKK, dan pemilik rumah singgah (homestay). Pada Tahun 2009, Pokdarwis telah mengantarkan desanya menjadi juara Desa Wisata se-Provinsi Daerah Istimewa Yogyakarta, hal tersebut menunjukkan bahwa kegiatan pemberdayaan masyarakat melalui pengembangan desa wisata telah dilakukan oleh masyarakat lokal yaitu Pokdarwis Nglanggeran yang telah mampu mengangkat potensi lokal menjadi potensi regional bahkan selanjutnya dapat diangkat menjadi potensi nasional.

Potensi alam desa Nglanggeran yang menjadi destinasi alam dan menarik perhatian masyarakat luas dapat dilihat dalam tabel 1 . 
Tabel 1. Potensi alam Desa Nglanggeran

\begin{tabular}{ll}
\hline Daya Tarik Alam & \\
\hline Daya tarik utama & $\begin{array}{l}\text { Adanya Gunung Api Purba dan panorama alam yang indah seperti air } \\
\text { terjun, perkebunan seperti buah nglanggeran, kakao, durian serta } \\
\text { panorama alam yang indah serta area pertanian dan persawahan di Desa } \\
\text { Nglanggeran }\end{array}$ \\
\hline Daya tarik pendukung & $\begin{array}{l}\text { Adanya Kawasan Embung (waduk mini) diatas bukit seluas 0,34 Ha } \\
\text { untuk pengairan kebun buah seluas 20 Ha dengan pemandangan yang } \\
\text { sangat indah }\end{array}$
\end{tabular}

\begin{abstract}
Daya Tarik Budaya
Daya tarik utama Upacara adat kirab budaya rasulan, atraksi kesenian jathilan, dan upacara adat masyarakat.

Daya tarik pendukung Kehidupan masyarakat desa dengan aktivitas gotong royong dan ramah, budaya kenduri, karawitan serta beberapa adat lokal yang masih terjaga.
\end{abstract}

\title{
Daya Tarik Kerajinan
}

\begin{tabular}{ll}
\hline Daya tarik utama & Adanya kerajinan kayu berupa topeng dan gelang \\
\hline Daya tarik pendukung & Adanya paket belajar membuat kerajinan yaitu batik topeng
\end{tabular}

Daya Tarik Kuliner

\begin{tabular}{ll}
\hline Daya tarik utama & Adanya makanan Khas dodol kakao dan Brownis Singkong \\
\hline Daya tarik pendukung & $\begin{array}{l}\text { Ada workshop pengolahan yang digunakan sebagai paket pendidikan } \\
\text { pembuatan dodol kakao dan brownis singkong }\end{array}$
\end{tabular}

\begin{tabular}{lll}
\hline Daya Tarik Buatan & & \\
\hline Daya tarik utama & $\bullet$ & Wahana permainan outbond, \\
& - Flying fox, \\
& - Embung (waduk mini) \\
& - Paket Pendidikan dialam (bertani, budidaya kakao, paket cinta \\
& & lingkungan) \\
\hline Daya tarik pendukung & - SDM dari pemuda yang masih energik \\
& Lokasi kegiatan yang representative \\
\hline
\end{tabular}

Dilihat dari aspek mata pencaharian, sebagian besar penduduk Desa Nglanggeran menggeluti bidang pertanian dan peternakan. Kedua sistem mata pencaharian ini memiliki fungsi yang saling melengkapi. Lahan yang digarap para petani sering menggunakan sistem tumpangsari, sehingga hasilnya dapat digunakan untuk memenuhi kebutuhan pakan ternak-ternak mereka, sementara itu kotoran ternak juga dapat untuk bahan dasar pupuk untuk kepentingan penyuburan tanah yang ditanami aneka tanaman. Ironinya adalah terdapatnya jumlah sejumlah angkatan kerja yang belum atau tidak bekerja, yang berdasarkan informasi dari kelurahan, masih juga kaum muda yang bekerja meski masih di usia produktif. Sistem mata pencaharian di masyarakat Desa Nglanggeran juga diwarnai 
oleh berbagai jenis profesi seperti PNS, perangkat desa, ibu rumah tangga dan pelajar atau mahasiswa.

Desa wisata adalah suatu bentuk integrasi antara atraksi, akomodasi dan fasilitas pendukung yang disajikan dalam suatu struktur kehidupan masyarakat yang menyatu dengan tata cara dan tradisi yang berlaku. Potensi alam, lahan pertanian, perkebunan yang didukung oleh kelompok sadar wisata sebagai pelaku pengembang desa sebagai destinasi adalah upaya memberdayakan masyarakat. Sinergisitas program pengembangan desa wisata antara kelompok sadar wisata, tokoh masyarakat, keterlibatan kelompok muda serta fasilitasi pemerintah desa merupakan sebuah persyaratan pembanguan yang keberlanjutan. Sinergisitas pengelolaan desa wisata yang berbasis potensi lingkungan alam, masyarakat, kehidupan pertanian dan perkebunan menjadi daya Tarik bagi peluang pengembangan desa wsiata. Pembangunan wisata desa tertentu tidak lepas dari intervensi kebijakan pemerintah, kemudahan akses terhadap teknologi, sumber daya manusia melalui pendidikan. Pendidikan kawasan wisata oleh masyarakat menjadi salah satu faktor pendorong terjadinya kreativitas, inovasi yang mendukung kawasan desa wisata semakin menarik kunjungan wisatawan.

Menurut Ritchie (2003) wisata edukasi adalah " a tourist activity undertaken by those who are undertaking an overnight vacation and those who are undertaking an excursion for whom education and learning is a primary or secondary part of their trip". Dari pernyataan tersebut, dapat disimpulkan bahwa wisata edukasi adalah kegiatan wisata yang dilakukan oleh individu atau kelompok ke suatu tempat dengan tujuan mendapatkan pengalaman pembelajaran. Melalui pembentukan kelompok sadar wisata, proses pembelajaran desa wisata di satu sisi mampu mengembangkana destinasi. Secara umum pembangunan yang terintegrasi dengan gerakan masyarakat seperti unsur usaha ekonomi produktif, unsur sosial kemasyarakatan, lingkungan bahkan politik yaitu melibatkan kebijakan-kebijakan memiliki potensi saling ketergantungan dan menguatkan satu sama lain. "...the development includes the process and policies by which a nation improves the economic, political and social well being of its people .." (Sheffrin, 2003)

Keberlanjutan pembangunan desa wisata memiliki beberapa persyaratan. Hampir sama dengan model pengembangan desa wisata di Desa Wisata Kuwu Kabupaten Grobogan Jawa Tengah dapat dikembangkan dengan lebih maksimal dan efisien jika masyarakat Kuwu bertindak proaktif. (Nur Indah Ariyani, 2014). Tindakan prokatif dalam pengembangan Desa Wisata Kuwu terlihat pada dilaksanakannya pentas seni secara swadaya oleh para pelaku seni di area Bledug Kuwu.

Kemitraan program kelompok sadar wisata yang didukung oleh kelompok kaum muda yang tergabung dalam organisasi karang taruna melalui gerakan literasi khususnya perpustakaan desa, maka tindakan-tindakan literasi yang konkrit. Sementara itu karangtaruna sebagai sebuah organisasi memiliki fungsi strategis sebagai kepanjangan tangan pemerintah desa untuk mendukung pengembangan desa wisata dengan membangun kesadaran literasi masyarakat luas agar unsur-unsur terkait destinasi seperti usaha produktif, optimalisasi lahan perkebunan serta penanaman nilai-nila keindahan, kebersihan, kejujuran, kerja sama dan peduli lingkungan. In particular, although they remain criticised for: (a) the problematic ways in which "communities," "partnership" and "stakeholders" are defined, delineated and constructed; (b) the lack of alignment and integration with local and national development planning policies and processes; (c) top-down governance, and the absence or 
erosion of participatory processes and empowerment goals; and (d) the tendency towards highly conservative development visions (McEwan, Mawdsley, Banks, \& Scheyvens, 2017), they remain a legitimisation strategy of international agencies and government for market oriented policies (Backstrand \& Kylsater, 2014).

Sekalipun desa wisata Nglanggeran memiliki predikat destinasi yang semakin tinggi bahkan menjadi desa wisata yang banyak dikunjungi desa-desa wisata di tanah air sebagai sarana studi banding, namun karena dianggap relatif masih baru maka tidak lepas dari permasalahan-permasalahan. Berdasarkan penjelasan pemerintah, di lihat dari aspek potensi desa Nglanggeran ini memadai namun dari aspek sumber daya masih memiliki problematik. Kaum muda atau generasi muda di daerah tersebut kurang tertarik menggarap potensi dari aspek sosial, budaya dan jasa. Banyak kaum muda dari desa tersebut hijrah ke daerah lain untuk menggeluti dunia usaha lain atau melakukan mobilitas di bidang pendidikan. Oleh karena hal tersebut keberlanjutan desa wisata pada 5 hingga 10 tahun ke depan masih memerlukan intervensi pemerintah, lembaga swasta lain yang berminat investasi atau memberikan pemikiranpemikiran dalam upaya membangun kesadaran literasi yang terintegrasi dengan program wisata terutama bagi masyarakat sekitarnya.

Melalui kegiatan penelitian ini, kolaborasi dengan pemerintah desa setempat, kelompok desa wisata serta lembaga pendidikan nonformal seperti TBM atau perpustakaan yang saat ini dikelola kelompok kaum muda menjadi sangat penting dalam mengembangkan desa wisata untuk meningkatkan kesadaran literasi masyarakat. Seperti fenomena yang cukup melekat di masyarakat saat ini, tidak hanya krisis ekonomi yang dihadapi oleh masyarakat Indonesia namun juga krisis literasi. Hal tersebut dibuktikan dengan hasil riset Central Connecticut State University 2016, yang menunjukan bahwa literasi Indonesia berada di tingkat kedua terbawah dari 61 negara, hanya satu tingkat di atas Botswana. Selain itu, menurut hasil riset UNESCO, yang juga mengungapkan bahwa hanya 1 dari 1000 orang di Indonesia yang membaca buku. Hal tersebut kemudian berakibat pada potensi resiko terhadap penyebaran konten negative di era digital ini. Hingga sebuah survey dari CIGI Ipsos 2016 memaparkan bahwa sebanyak 65 persen dari 132 juta pengguna internet di Indonesia percaya dengan kebenaran informasi di dunia maya tanpa cek dan ricek.

Krisis literasi tersebut kemudian cukup mengerakkan semua elemen masyarakat untuk saling menyadarkan dan meningkatkan kesadaran masyarakat. Istilah 'literasi' dapat diartikan sebagai sesuatu yang berhubungan dengan tulis-menulis, keberaksaraan, atau melek aksara. Dalam konteks kekinian, literasi memiliki definisi dan makna yang sangat luas. Literasi bisa berarti melek teknologi, politik, berpikiran kritis dan peka terhadap lingkungan sekitar. Maka secara sederhana, budaya literasi dapat didefinisikan sebagai kemampuan di mana setiap orang memiliki sikap cerdas, peka, jeli, pembelajar, berbudaya, mampu membaca lingkungannya dan mampu mengaktualisasikan dalam tulisan atau karya. Membangun kesadaran literasi dalam konteks pengembangan desa wisata di diawali dengan analisis potensi dan masalah, sehingga diperlukan kreativitas, inovasi dan melek literasi dalam cara berpikir. Dengan demikian kesadaran literasi bukan sekedar membaca namun lebih dari sebagaimana didefinisikan oleh UNESCO, pemahaman orang tentang literasi sangat dipengaruhi oleh penelitian akademik, institusi, konteks nasional, nilainilai budaya dan pengalaman. Polat and Hermans (2016) developed a sustainable accessible tourism model to evaluate the 
potential ways for disabled people to intensively join in (or be accessible to) tourism activities with the highest level of experience. "Responsustabel tourism" was defined by merging two words, i.e., responsible (practice and behavior-based) and sustainable (concept and values-based) (Mihalic, 2016). Prospective tourists are interested in the wider aspects of the tourism experience which in turn require the careful management of social and environmental resources in Small Island Developing States (Grili, et.al, 2020). Education Development Center (EDC) menyatakan bahwa literasi lebih dari sekedar kemampuan membaca dan menulis, namun lebih dari itu. Ade Mesti Anugrah dalam Kompasiana beyond blogging yang diposting 22 desember 2018 tentang pentingnya membangun kesadaran literasi bagi anak muda). Literasi adalah kemampuan individu untuk menggunakan segenap potensi dan kemampuan yang dimiliki dalam hidupnya.

Kemampuan membaca kata dan membaca dunia adalah seni literasi. Tetapi sayangnya kita terjebak pada cara berpikir yang pendek, literasi dipahami sebagai kemampuan membaca teks dan menghitung numerik. Ini terlalu minimalis sehingga nantinya bisa menjebak kita pada kepentingan skill literasi, padahal skill literasi adalah buah dari kesadaran yang substansial. Dalam konteks ini, sebagai bangsa dengan jumlah penduduk lebih dari 250 juta jiwa, dengan jumlah lembaga pendidikan dan perguruan tinggi yang terus meningkat, apakah Indonesia telah memiliki tradisi literasi yang baik? Tentu saja belum. Hal ini sinergis dengan data yang dilansir oleh Central Connecticut State University di New Britain, Amerika Serikat, menempatkan lima negara pada posisi terbaik yaitu Finlandia, Norwegia, Islandia, Denmark, dan Swedia. Dan kita mungkin terkejut ketika mengetahui Indonesia pada posisi 60 dari 61 negara. Indonesia hanya setingkat lebih tinggi dari
Botswana, sebuah negara di Afrika. (The Jakarta Post, 12 Maret 2016). Hasil penelitian di atas menunjukkan betapa lemahnya budaya literasi dalam masyarakat Indonesia. Beberapa ahli menjelaskan tentang faktor-faktor penyebab rendahnya literasi. Menurut Fadriyani (2010) tedapat faktor yang dapat mempengaruhi literasi, yaitu intelegensi, jenis kelamin, perkembangan motorik, kondisi fisik, kesehatan fisik, lingkungan, perbedaan status sosial keluarga, termasuk di dalamnya keterlibatan orangtua.

Bangsa kita masih mengandalakan apa yang dilihat (visual) dan didengar (audio) dalam berpikir, bersikap, dan bertindak. Berdasarkan sensus Badan Pusat Statistik (BPS) di 2006 menunjukkan 85,9 persen masyarakat memilih menonton televisi daripada mendengarkan radio (40,3 persen) dan membaca koran (23,5 persen). Kita belum terbiasa melakukan sesuatu berdasarkan pemahaman dari membaca. Kita belum dapat mengaktualisasikan diri melalui tulisan. Membaca dan menulis belum menjadi budaya dan tradisi bangsa kita. Berdasarkan gambaran permasalahan di atas, maka kegiatan ini di fokuskan pada upaya membangun literasi di desa wisata nglanggeran dengan sinergi yang dilakukan dengan karangtaruna dan program taman bacaan masyarakat yang digalakan oleh pemerintah kabupaten Gunung Kidul. Sehingga kegiatan ini dapat saling berkolaborasi dengan tiap unsur dan elemen masyarakat.

\section{METODE}

Informan dalam kegiatan ini adalah kelompok Sadar Wisata, kelompok kaum muda yang tergabung dalam organisasi karang taruna sekaligus penggerak peningkatan budaya literasi serta tokoh masayarakat dan pendamping program pemberdayaan masyarakat desa Nglanggeran. Mekanisme kegiatan dilakukan melalui tahapan baik jangka 
pendek maupun panjang, mulai dari analisis kebutuhan hingga pendampingan. Metode yang digunakan dalam pengumpulan data ini dengan wawancara, observasi, dokumentasi maupun focus group discussion melalui aktivitas penyuluhan komunal, penyuluhan individual, pendampingan dan fasilitas sumber belajar literasi. Hasil dari kegiatan ini kemudian di analisis secara deskriptif kualitatif dengan data yang terkumpul. Sehingga secara garis besar dengan menggunakan pendekatan kualitatif.

\section{HASIL}

Desa Nglanggeran Kecamatan Patuk Gunung Kidul merupakan lokasi penelitian yang panorama, keindahan sudah dikenal oleh masyarakat luas juga dari manca negara. Teknologi, komunikasi dan informasi yang begitu cepat berkembang memudahkan wilayah-wilayah yang memiliki sumber daya alam menonjol dengan mudah dapat disebarluaskan. Demikian juga daerah Nglanggeran yang merupakan destinasi sekalipun dipandang relative masih baru namun oleh karena kreativitas, inovasi dan transformasi informasi secara daring, maka wilayah ini mencjadi destinasi yang semakin berkembang.

Seiring dengan perkembangan potensi alam yang dikelola dengan baik, Langgeran bukan hanya terkenal sebagai destinasi yang menunjukkan gunung merapi purbanya, panorama, telaga dan air terjun yang mempesona namun jasa omah penginapan, kuliner, perkebunan dengan buah-buag Langgeran menjadi daya tarik tersendiri. Perkembangan cepat tentang Langgeran yang semakin diminati banyak kalangan ini juga disadari oleh warga masyarakat, sehingga dengan kreativitas masing-masing atau oleh karena upaya pemerintah bersama dengan pihak swasta lain, dibangunnya lah pusat-pusat kuliner, puat pertunjukan seni berbasis potensi masyarakat. Geliat ekonomi produktif, ekonomi kerakyatan semakin diperkuat oleh fasilitasi kebijakan, infrastruktur seperti jalanjalan maka menjadi semakin tampak sebagai sebuah desa yang berkembang, menarik dan mempesona.

\section{Pelaksanaan Kegiatan}

Kegiatan ini dilaksanakan oleh tim dengan menghadirkan khalayak sasaran dengan asumsi bahwa pengintegrasian program pengembangan desa wisata oleh kelompok sadar wisata, karang taruna, tokoh masyarakat dan perwakilan dari pemerintaha desa yaitu unit pemberdayaan organisasi pemuda atau karang taruna. Sesuai dengan analisis situasi, potensi dan permasalahan desa wisata sebagaimana yang dipahami peneliti sebelum kegiatan ini berlangsung, maka rintisan TBM sebagai pengerak sadar literasi bagi masyarakat menjadi sangat penting, terlebih dalam mengembangkan desa wisata juga sangat perlu keterlibatan masyarakat secara keseluruhan oleh karena potensi alam yang ada tidaklah cukup berkembang jika tanpa campur tangan sumber daya manusia, tingkat keterbacaan atau melek literasi, sadar akan potensi, masalah serta menemukan pemecahan masalah (problem solving) adalah serangkaian prasyarat terjadinya pengembangan destinasi berbasis teknologi informasi.

Kegiatan pengumpulan data di awali dengan sarasehan melalui penyampaian harapan oleh pemerintah desa melalui karang taruna yang saat ini masih menggunakan pengelola perpustakaan desa. Demikian juga kelompok sadar wisata yang lebih dulu mengelola desa wisata juga tidak lepas dari permasalahan yaitu kurang nya fasilitas layanan sosial untuk para wisatawan. Sementara itu tokoh masyarakat yang sejak awal memiliki kepedulian yang besar bukan hanya mengajak untuk mengembangkan desa wisata namun pada dasarnya tokoh masyarakat 
yang diundang dalam kegiatan ini memiliki kelebihan. Salah satu kelebihan nya adalah dalam hal melakukan inovasi peningkatan hasil pertaniannya, melakukan budidaya buah coklat yang tidak kenal lelah hingga menyediakan tempat tinggalnya untuk beraktivitas kaum muda dalam membahas, menemukan masalah, potensi serta mencari solusi atas problem desa wisata.

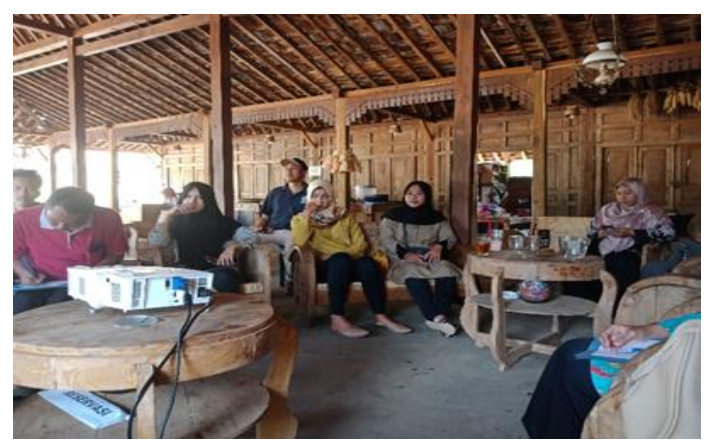

Gambar 1. Setting sarasehan Karang taruna, Kelompok Sadar Wisata, dan Tokoh Masyarakat

Sarasehan yang pada dasarnya adalah bentuk pertukaran pengalaman ini dilengkapi dengan diskusi, Tanya jawab dan menumbuhkan niat untuk merancang program secara terpadu antara karang taruna dan kelompok sadar wisata dengan pemerintah desa dan tokoh masyarakat sebagai pembinanya. Materi sarasehan yang disajikan adalah keterkaitan antara Taman Bacaan Masyarakat dan kebutuhan desa wisata tentang kesadaran literasi.

BAGAIMANA KAITAN TBM DENGAN DESA WISATA

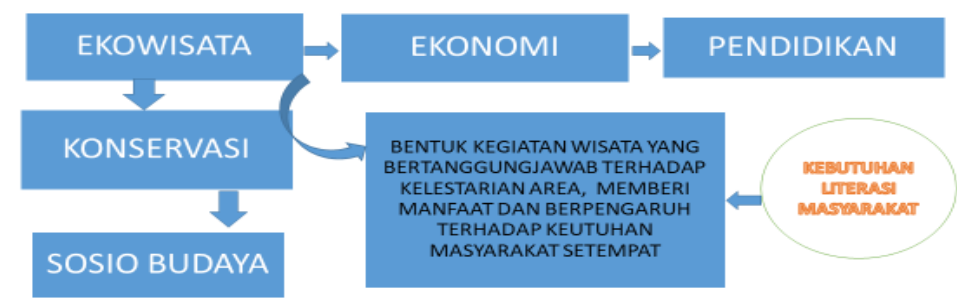

Gambar 2. Kaitan TBM dengan Desa Wisata

Skema ini menunjukkan bahwa kesadaran literasi, peduli desa wisata menjadi orientasi kebutuhan masyarakat dan pemahaman masyarakat tentang desa wisata tersebut. Salah satu layanan publik yang cukup besar pengaruhnya yaitu aksistensi TBM atau perpustakaan desa. Secara umum masyarakat literate memiliki pemahaman tentang unsur ekowissata sebagai konservasi sosial budaya dan berkaitan dengan usnur ekonomi produktif yang ditopang oleh pendidikan merupakan serangkaian gambaran kebutuhan belajar masyarakat yang perlu diperhatikan. Sarasehan dengan metode diskusi dan tanya jawab ini mengisyaratkan akan pentingnya usaha mengembangkan desa wisata dalam sebuah keterpaduan program dalam kelompok sadar wisata dan masyarakat luas.

Model sarasehan, berbagi pengetahuan, pengalaman untuk menemukan rumusan yang tepat tercapainya sinergisitas program kelompok sadar wisata dan karang taruna melalui rintisan taman bacaan yang mendukung pengembangan desa wisata dari sisi kesadaran literasi masyarakat, pengembangan usaha produktif, kreativitas, inovasi kaum muda dalam seni pertunjukan, serta kesadaran akan peduli desa wisata dan lingkungan. Kegiatan sarasehan yang selanjutnya diteruskan mealui model pendampingan yang dipadukan dengan kegiatan PPL KKN mahasiswa serta pendampingan-pendampingan oleh kelompokkelompok yang terkait seperti pemerintah desa, karang taruna, tokoh masyarakat dan kelompok sadar wisata. Pendampingan secara langsung di lapangan ini bertujuan untuk menghasilkan kemandirian serta keterampilan problem solving sesuai kebutuhan masyarakat. Kesadaran literasi masyarakat bukanlah sesuatu yang muncul begitu saja akan tetapi melalui proses sosialaisasi, melakukan kegiatan-kegiatan rutin dan insudental sesuai dengan agenda program desa wisata serta kesadaran literasi masyarakat agar memiliki kemampuan mengembangkan potensinya 
dalam berbagai sektor seperti budidaya tanaman, oubond oleh karang taruna.

Harapan untuk terbentuknya rintisan Taman Bacaan Masyarakat (yang saat ini dikenal dengan perpustakaan desa) oleh karang taruna oleh karena kesadaran yang tinggi dari pemerintah desa, tokoh masyarakat bahwa sinergistias program oleh lebih banyak komponen masyarakat justru mampu mengembangkan desa wisata dari beberapa aspek. Salah satu aspek yang direncanakan adalah melalui rintisan TBM oleh karang taruna, akan semakin banyaklah masyarakat memperoleh kayanan belajar sesuai kebutuhan. Rintisan TBM yang akan dirintis eksistensinya juga memiliki fungsi strategis dalam membelajarkan masyarakat, meningkatkan kesadaran literasi, sehingga masyarakat dengan talentanya masing-masing dapat melengkapi kebutuhan desa wisata seperi penyediaan jasa penginapan, jas kuliner, lahan untuk budidaya buah Nglanggeran maupun coklat yang subur tumbuh di tanah perkebunan desa ini.

Untuk membangun rintisan TBM yang mendukung kesadaran literasi dan peduli desa wisata bagi seluruh masyarakat diperlukan intervensi pendidikan non formal. Namun demikian kurangnya pemahaman mengenai konsep TBM disebabkan karena beberapa hal, sumber daya manusia yang masih silih berganti dan transfer pemahaman tentang taman bacaam masyarakat masih belum memadai. Penelitian ini memberi harapan baru bagi pemerintah desa bahwa keterlibatan karang taruna menjadi bentuk layanan kebutuhan taman bacaan masyarakat sebagai kebutuhan anak anak di Nglanggeran.

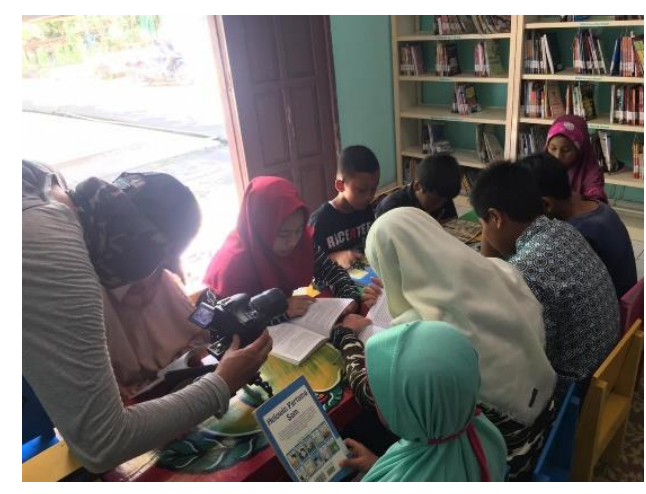

Gambar 3. Kegiatan peningkatan kesadaran literasi oleh kaum muda Nglanggeran

Kegiatan ini menghasilkan kesepakatan terbentuknya rintisan taman bacaan masyarakat (perpustakaan desa) yang mendukung pengembangan desa wisata. Taman Bacaan Masyarakat yang dikenal cukup luas di dunia pendidikan nonformal. Perpsutakaan yang berkaitan dengan destinas di Langgeran mencakup beberapa rancangan:

1. Gerakan masyarakat yang peduli sadar wisata, masyarakat yang literate. Gerakan ini diwujudkana dengan pembuatan tulisan nilai yang layak ditanamkan pada anakanak hingga dewasa.

2. Membentuk TBM berbasis lingkungan dan kearifan lokal. Sehingga aktivitas masyarakat yang literate, peduli desa wisata semakin konkrit, terarah dan terstruktur.

3. Gerakan masyarakat yang berorientasi ke bidang kuliner, penginapan, serta tempat rekreasi yang nyaman menjadi salah satu penguatan kelompok sadar wisata, untuk mengintegrasikan program-programnya ke program atau kegiatan masyarakat untuk pengembangan desa wisata. Konstribusi yang lahir dari desa wisata untuk membangkitkan semangat literasi untuk terjadinya kolaborasi unsur lingkungan alam, ekonomi dan sosial. 


\section{PEMBAHASAN}

\section{Gerakan Masyarakat dalam Membangun Kesadaran Literasi}

Istilah 'literasi' dapat diartikan sebagai sesuatu yang berhubungan dengan tulismenulis, keberaksaraan, atau melek aksara. Dalam konteks kekinian, literasi memiliki definisi dan makna yang sangat luas. Literasi bisa berarti melek teknologi, politik, berpikiran kritis dan peka terhadap lingkungan sekitar. Maka secara sederhana, budaya literasi dapat didefinisikan sebagai kemampuan di mana setiap orang memiliki sikap cerdas, peka, jeli, pembelajar, berbudaya, mampu membaca lingkungannya dan mampu mengaktualisasikan dalam tulisan atau karya. Membangun kesadaran literasi dalam konteks pengembangan desa wisata di diawali dengan analisis potensi dan masalah. Potensi alam desa Nglanggeran sudah bukan hal yang baru lagi, namun dari aspek sumber daya manusia potensi yang ada di masyarakat masih memerlukan kesadaran bersama agar setiap kelompok pemuda menjadi tertarik untuk bersama membangun desa menjadi destinasi berbasis lingkungan alam yang memang sesungguhnya sudah tersedia. Sehingga diperlukan kreativitas, inovasi dan melek literasi dalam cara berpikir. Seperti kegaiatan yang dilakukan oleh kelompok sadar wisata dalam memberikan pemahaman kepada masyarakat mulai dari anak anak dengan berbagai kegiatan. Seperti hasil penelitian Wijaya, Zulkarnain, dan Sopingi (2018) yang menyatakan bahwa sosialisasi sebagai bentuk tanggung jawab mereka dalam menyadarkan dan membimbing masyarakat akan wisata. Dan hasil penelitian Nadiasari dan Nurhadi (2019) yang juga menyebutkan bahwa sosialisasi menjadi satu tahapan dalam pengorganisasian Kelompok Sadar Wisata. Dengan demikian kesadaran literasi bukan sekedar membaca namun lebih dari sebagaimana didefinisikan oleh UNESCO, pemahaman orang tentang literasi sangat dipengaruhi oleh penelitian akademik, institusi, konteks nasional, nilai-nilai budaya dan pengalaman. Education Development Center (EDC) menyatakan bahwa literasi lebih dari sekedar kemampuan membaca dan menulis, namun lebih dari itu. Ade Mesti Anugrah dalam Kompasiana beyond blogging yang diposting 22 desember 2018 tentang pentingnya membangun kesadaran literasi bagi anak muda). Literasi adalah kemampuan individu untuk menggunakan segenap potensi dan kemampuan yang dimiliki dalam hidupnya.

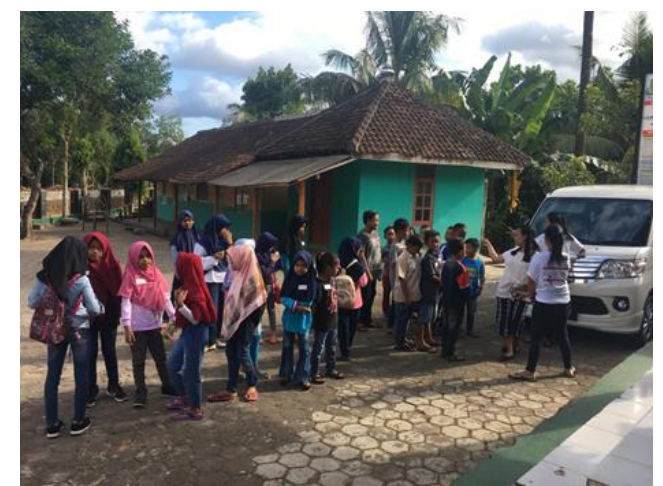

Gambar 4. Kegiatan kesadaran literasi melalui kegiatan karang taruna

\section{Sinergisitas Program Pengembangan Desa Wisata dan Keterlibatan Karang taruna}

Pengembangan program desa wisata dengan model kemitraan antara satu potensi dan potensi memiliki pengaruh terhadap satu penguatan kelompok atau lembaga pengembang destinasi. Martinez et.al (2019) menyatakan bahwa tourism is a key sector in the sustainable development of rural environments. Its ability to create stabel employment and an acceptabel level of profits is conditioned by the stability of tourist activity throughout the year. Oleh karena unsur literasi, pendidikan menjadi salah satu pendukung terintegrasinya program dengan program yang lain maka unsur kemitraan menjadi sebuah 
upaya yang tidak bisa diabaikan. Salah satu alasannya adalah sebuah upaya pembangunan tanpa didukung oleh sumber daya manusia hanya melalui pendidikan wisata kemudian menjadi suatu gerakan masyarakat maka keberlanjutan program dimungkinkan untuk terjadi.
Kegiatan analisis kebutuhan dilakukan di awal untuk mengetahui potensi, kebutuhan hingga masalah khususnya di desa wisata nglanggeran. Berdasarkan informasi yang didapatkan dari kelompok pokdarwis, berikut gambaran kegiatan yang dilakukan.

Tabel 2. analisis kebutuhan

\begin{tabular}{|c|c|c|c|c|}
\hline No & Materi & $\begin{array}{c}\text { Problema desa } \\
\text { wisata }\end{array}$ & Metode & Luaran \\
\hline 1 & $\begin{array}{l}\text { Potensi } \\
\text { sumber daya } \\
\text { manusia, alam } \\
\text { dan kebijakan } \\
\text { pengembangan } \\
\text { desa wisata }\end{array}$ & $\begin{array}{lr}\text { Kelompok } & \text { sadar } \\
\text { wisata } & \text { yang } \\
\text { mengembangkan } \\
\text { program } & \text { literasi } \\
\text { berbasi } & \text { digital } \\
\text { namun } & \text { belum } \\
\text { melibatkan } & \\
\text { organisai } & \text { karang } \\
\text { taruna } & \text { dengan } \\
\text { kemampuan } & \\
\text { literasinya } & \text { melalui } \\
\text { TBM } & \\
\end{array}$ & $\begin{array}{l}\text { Ceramah, kunjungan daerah wisata } \\
\text { Tanya jawab dan merumuskan } \\
\text { program/kegiatan }\end{array}$ & $\begin{array}{l}\text { Membuat disain fisik dan non } \\
\text { fisik taman bacaan yang } \\
\text { menekankan pada kesadaran } \\
\text { literasi masyarakat terhadap } \\
\text { desa wisata }\end{array}$ \\
\hline 2 & $\begin{array}{l}\text { Analisis } \\
\text { Taman Bacaan } \\
\text { dan } \\
\text { prospeknya } \\
\text { terhadap } \\
\text { peningkatan } \\
\text { kapsitas } \\
\text { literasi } \\
\text { masyarakat }\end{array}$ & $\begin{array}{l}\text { Terdapat } \\
\text { perpustakan yang } \\
\text { belum sepenuhnya } \\
\text { mendukung } \\
\text { program desa } \\
\text { wisata }\end{array}$ & $\begin{array}{l}\text { Sarasehan } \\
\text { Fasilitasi pemerintah desa. } \\
\text { Diskusi } \\
\text { Sharing pengalaman } \\
\text { Brain storming }\end{array}$ & $\begin{array}{lr}\text { Rancangan } & \text { pembuatan } \\
\text { berbagai bentuk tulisan } \\
\text { penyemangat tentang gerakan } \\
\text { tentang kebersihan, } \\
\text { keramahan, layanan prima, } \\
\text { buku informasi tentang desa } \\
\text { wisata }\end{array}$ \\
\hline 3 & $\begin{array}{l}\text { Pendampingan } \\
\text { dan evaluasi } \\
\text { dalam jangka } \\
\text { waktu } 1 \text { tahun } \\
\text { hingga } 3 \text { tahun } \\
\text { ke depan }\end{array}$ & $\begin{array}{l}\text { Keberlangsungan } \\
\text { program rintisan } \\
\text { taman bacaan }\end{array}$ & Kunjungan secara periodic & 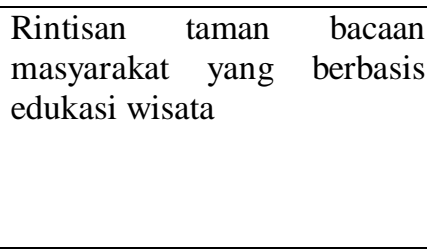 \\
\hline
\end{tabular}

Sesuai dengan analisis kebutuhan kemudian disepakati kegiatan difokuskan pada aspek peningkatan kesadaran literasi masyarakat. Seperti yang kita pahami dari konsep literasi berasal dari bahasa latin littera yang memiliki arti pelibatan sistem tulisan yang menyertainya. Selain itu, literasi menjadi hak asasi setiap insan yang fundamental dan pondasi bagi tiap individu untuk terus belajar sepanjang hayat. Yang sesuai dengan tujuan dari UNESCO (2015) yang menyatakan bahwa literasi akan berpengaruh pada pembangunan social dan manusia dalam kemampuannya untuk dapat mengubah kehidupannya. Sehingga literasi tidak hanya kemampuan untuk membaca dan menulis namun juga penambahan pengetahuan, kemampuan dan ketrampilan yang dapat membuat seseorang lebih mampu berpikir kritis, mampu memecahkan masalah dalam berbagai konteks serta berkomunikasi secara efektif dan mampu mengembangkan potensi dan partisipasi aktif 
dalam tiap kegiatan bermasyarakat. (Alberta. 2009). Terkait dengan hal tersebut, National Literacy Forum (2014) menyatakan bahwa ada empat cara yang harus dilakukan dalam membangun literasi yang universal yaitu: meningkatkan kemampuan bahasa sejak dini di rumah dan dalam pendidikan non formal, lebih mengefektifkan pembelajaran yang dapat menumbuhkan keterampilan membaca dan menulis di sekolah, adanya akses untuk membaca dan program yang membuat anak merasa senang melakukan kegiatan literasi, menciptakan kerjasama antara sekolah, lingkungan, keluarga dan lingkungan kerja untuk dapat mendukung budaya literasi.

Potensi, program, kegiatan usaha produktif, seperti jasa penginapan, kuliner maupun optimalisasi potensi alam yang belum tampak merupakan problema oleh karena generasi muda yang lebih memilih hijrah ke kota untuk mengembangkan kesejahteraannya. Prinsip dari kita untuk kita dan oleh kita dalam pengembangan wisata memerlukan berbagai bentuk kolaborasi, kemitraan berbasis program dengan inovasi literasi, kreativias dan kerja keras. Dengan memadukan protensi, program kelompok sadar wisata, karang taruna, tokoh masyarakat yang peduli desa wisata serta keperpihakan pemerintah desa maka model kemitraan menjadi salah satu model penguatan kelompok sadar wisata yang selama ini masih berkirpah secara kelompok tanpa melibatkan potensi lain seperti karang taruna sebagai penggerak motivasi belajar dan berusaha melalui rintisan taman bacaannya. Kegiatan ini berusaha untuk menemukan pola kemitraan dalam meningkatkan kesadaran literasi masyarakat antara kelompok sadar wisata dengan karang taruna untuk saling menguatkan agar terbentuk rintisan tamana bacaan atau perpustakaan desa yang semakin dibutuhkan masyarakat.

Adapun bentuk penyuluhan komunal yang dilakukan melalui kegiatan sarasehan.
Model sarasehan dipilih agar memiliki makna kedekatan, kebersamaan dan tidak terkesan formal dalam mempertemukan kelompok sadar wisata, karang taruna yang sebagian besar adalah kaum muda serta tokoh masyarakat bersama pemerintah desa. Tema tentang kesadaran literasi ini dipilih dengan pertimbangan adanya permasalahan yang dirasakan yaitu kelompok sadar wisata yang memerlukan partner dalam mengembangkan potensi wisata. Sekalipun kelompok sadar wisata telah memiliki situs layanan secara online serta jaringan yang luas termasuk dengan pihak luar negeri akan tetapi tidak semua potensi tergarap secara optimal oleh karena keterbatasan sumber daya manusia.

Kegiatan yang dilakukan berjalan dengan lancar dan tidak terlepas dari beberapa hal yang mendukung maupun menghambat yaitu selama kegiatan ini berlangsung, potensi alam yang sangat mendukung maka kebijakan pemerintah desa, menjadi salah satu factor pendukung. Selain itu, kerjasama yang dibangun tim antara kelompok desa wisata dan karang taruna adalah masing-masing saling menguatkan. Dari pihak perwakilan dari pemberintah desa sudah cukup untuk keberhasilan sebuah kegiatan pengembangan desa wisata. Serta kepedulian tokoh masyarakat, terhadap pengembangan desa wisata membantu untuk bisa berkomunikasi. Di sisi lain, hal hal berikut yang dirasa oleh tim masih menjadi penghambat dari kegiatan diantaranya yaitu secara geografis desa Langgeran begitu luas, sehingga setiap informasi tentang kondisi umum desa tersebut. Sebaiknya dilakukan kegiatan untuk mengembangkan dan menerapkan hasil temuannya, karena setiap keluarga belum memiliki kemampuan yang sama. Serta harus di imbangi oleh upaya upaya untuk membangun kesadaran literasi yang dikelola karang taruna. 
Seperti konsep pembangunan kepariwisataan yang selalu memerlukan dukungan dan keterlibatan seluruh pemangku kepentingan di bidang pariwisata. Collaboration need to extend well beyond the narrowly envisaged public-private partnerships (Hall, 2019). Addressing the social and cultural indicators would be more challenging because they often defy simple resolution and require industry- and community-wide involvement and commitment (Agyeiwaah et al., 2017). Masyarakat adalah salah satu unsur penting pemangku kepentingan untuk bersama-sama dengan Pemerintah dan kalangan usaha/swasta bersinergi melaksanakan dan mendukung pembangunan kepariwisataan, oleh karena itu pembangunan kepariwisataan harus memperhatikan posisi, potensi dan peran masyarakat baik sebagai subjek atau pelaku maupun penerima manfaat pengembangan, karena dukungan masyarakat turut menentukan keberhasilan jangka panjang pengembangan kepariwisataan. Dukungan masyarakat dapat diperoleh melalui penanaman kesadaran masyarakat akan arti penting pengembangan kepariwisataan, untuk itu dibutuhkan proses dan pengkondisian untuk mewujudkan masyarakat yang sadar wisata. To promote sustainable tourism, Sanches-Pereira et al. (2017) proposed a set of potential thematic strategies: (i) public awareness and citizen's capacity building, (ii) start-up drivers, (iii) public-private partnerships and destination level cooperation and action, and (iv) effective promotion of pro-poor tourism and branding.

Berdasarkan kegiatan ini mengingatkan kembali pada peran penting Kelompok Sadar Wisata (Pokdarwis) yang merupakan salah satu komponen dalam masyarakat yang memiliki peran dan kontribusi penting dalam pengembangan kepariwisataan di daerahnya. Keberadaan Pokdarwis tersebut perlu terus didukung dan dibina sehingga dapat berperan lebih efektif dalam turut menggerakkan partisipasi masyarakat untuk mewujudkan lingkungan dan suasana yang kondusif bagi tumbuh dan berkembangnya kegiatan kepariwisataan di sekitar destinasi pariwisata. Pedoman Kelompok Sadar Wisata (2012) menyatakan bahwa Peningkatan peran masyarakat dalam pembangunan kepariwisataan memerlukan berbagai upaya pemberdayaan (empowerment), agar masyarakat dapat berperan lebih aktif dan optimal serta sekaligus menerima manfaat positif dari kegiatan pembangunan yang dilaksanakan untuk peningkatan kesejahteraannya.

Pemberdayaan Masyarakat dalam konteks pembangunan kepariwisataan dapat didefinisikan sebagai "Upaya penguatan dan peningkatan kapasitas, peran dan inisiatif masyarakat sebagai salah satu pemangku kepentingan, untuk dapat berpartisipasi dan berperan aktif sebagai subjek atau pelaku maupun sebagai penerima manfaat dalam pengembangan kepariwisataan secara berkelanjutan". Renstra Dit. Pemberdayaan Masyarakat (2010). Definisi tersebut menegaskan posisi penting masyarakat dalam kegiatan pembangunan, yaitu masyarakat sebagai subjek atau pelaku pembangunan, dan masyarakat sebagai penerima manfaat pembangunan. Masyarakat sebagai subyek atau pelaku pembangunan, mengandung arti, bahwa masyarakat menjadi pelaku penting yang harus terlibat secara aktif dalam proses perencanaan dan pengembangan kepariwisataan, bersama-sama dengan pemangku kepentingan terkait lainnya baik dari pemerintah maupun swasta. Implementation strategies on sustainable tourism development require cross-sectoral linkages. It is especially imperative to address the institutional and structural challenges faced by tourism sectors. The effective operations of the tourism economy largely depend on the institutional 
arrangements and structural frameworks within the entire social economic system (Tang, 2017)

Berdasarkan fungsinya sebagai subjek atau pelaku masyarakat memiliki peran dan tanggung jawab untuk bersama-sama mendorong keberhasilan pengembangan kepariwisataan di wilayahnya. Masyarakat sebagai penerima manfaat, mengandung arti, bahwa masyarakat diharapkan dapat memperoleh nilai manfaat ekonomi yang berarti dari pengembangan kegiatan kepariwisataan untuk meningkatkan kualitas hidup dan kesejahteraan sosial masyarakat yang bersangkutan. Prospects of the potential for tourism to contribute to the transformative changes, e.g., a green economy system, are illustrated (Pan, et.al, 2018). Returns to the theoretical relationship between tourism and sustainable development, considering more recent transformations in understandings of the concept of development as well as contemporary approaches to sustainable development. Highlighting the controversy surrounding the continuing adherence to economic growth in development policy in general and tourism development in particular, it discusses sustainable de-growth as an alternative approach to development and, in the context of increasing concerns over climate change, the specific implications for tourism (Sharpley, 2020). Dalam kerangka pembangunan kepariwisataan tersebut, salah satu aspek mendasar bagi keberhasilan pembangunan kepariwisataan adalah dapat diciptakannya lingkungan dan suasana kondusif yang mendorong tumbuh dan berkembangnya kegiatan kepariwisataan di suatu tempat. Iklim atau lingkungan kondusif tersebut terutama dikaitkan dengan perwujudan Sadar Wisata dan Sapta Pesona yang dikembangkan secara konsisten di kalangan masyarakat yang tinggal di sekitar destinasi pariwisata. Sadar wisata dalam hal ini digambarkan sebagai bentuk kesadaran masyarakat untuk berperan aktif dalam 2 (dua) hal berikut, yaitu: a) Masyarakat menyadari peran dan tanggung jawabnya sebagai tuan rumah (host) yang baik bagi tamu atau wisatawan yang berkunjung untuk mewujudkan lingkungan dan suasana yang kondusif sebagaimana tertuang dalam slogan Sapta Pesona. b) Masyarakat menyadari hak dan kebutuhannya untuk menjadi pelaku wisata atau wisatawan untuk melakukan perjalanan ke suatu daerah tujuan wisata, sebagai wujud kebutuhan dasar untuk berekreasi maupun khususnya dalam mengenal dan mencintai tanah air

\section{SIMPULAN}

Gerakan masyarakat meningkatkan kesadaran literasi menjadi bagian proses pembangunan yang mengedepankan keberlanjutan. Makna gerakan masyarakat dalam hal ini mengajak masyarakat untuk peduli terhadap pengembangan desa wisata yang pada kenyataannya tidak bisa hanya dikembangkan, dinikmati oleh kelompok tertentu. Program yang telah dikembangkan kelompok sadar wisata ternyata belum cukup sehingga keterlibatan masyarakat untuk mendukung desa wisata dari aspek sosial, sumber daya manusia, ekonomi dan teknologi merupakan sinergisitas unsur pembangunan yang tidak mungkin diabaikan.

Membangun kesadaran literasi bagi seluruh masyarakat menjadi penting terutama dalam mensikapi berkembangnya desa wisata dengan potensi alam yang begitu mempesona wisatawan. Untuk itulah kolaborasi kelompok sadar wisata dengan program pengembangan yang didukung taman bacaan masyarakat yang memenuhi kebutuhan belajar masyarakat kaitannya dengan gerakan mendukung desa wisata. Prinsi sinergisitas, keberlanjutan dan prinsip menjaga keharmonisan alam dan sumber daya manusia merupakan kesepakatan 
sosial yang tampak dalam pertumbuhan rumah penginapan, kuliner, budidaya coklat serta berkembangnya seni tradisional.

Program pengembangan kelompok sadar wisata dengan mengintegrasikan gerakan kesadaran literasi dengan cara melakukan penanaman nilai melalui tulisan-tulisan berbasis nilai kebersihan, kerjasama, disiplin, jujur di berbagai tempat strategis dalam jangka waktu pendek akan segera diwujudkan. Karang taruna sebagai generasi muda yang peduli lingkungan, pendidikan wisata dan nilai keadilan dan kerakyatan bagus bila disertai dengan fasilitasi pemerintah desa. Untuk itu pemerintah desa secara terstruktur bersama dengan karang taruna melakukan pendampingan dalam kegiatan rutin maupun incidental. Penyediaan buku-buku informatif tentang Desa Wisata Nglanggeran beserta situs, tempat-tempat rekreasi maupun cerita-cerita yang berkaitan dengan keberadaan geopark yang ditempatkan pada rumah-rumah penginapan juga sangat membantu pembelajaran masyarakat secara lebih luas

\section{DAFTAR RUJUKAN}

Agyeiwaah, E., McKercher, B., \& Suntikul, W. (2017). Identifying core indicators of sustainable tourism: A path forward?. Tourism Management Perspectives, 24, 26-33.

Arif, S. Gunawan.(2016). Indonesia second least literate of 61 nations. The Jakarta Post. Sat.March 12.

Backstrand, K., \& Kylsater, M. (2014). Old wine in new bottles? The legitimation and delegitimation of UN publicprivate partnerships for sustainable development from the Johannesburg Summit to the Rio p 20 Summit. Globalizations, 11(3),331-347. doi:10.1080/14747731.2014.892398

Bryan, D., Rafferty, M., \& Wigan, D. (2017). Capital unchained: Finance, intangible assets and the double life of capital in the offshore world. Review of International Political Economy, 24(1),56-86. doi:10.1080/ 09692290.2016.1262446

Dhanik Nor Palupi Rorah. (2012). Pengelolaan Pariwisata Berbasis Masyarakat (Community

Based Tourism ) di Desa Wisata Kebonagung Kecamatan Imogiri. Universitas Negeri

Yogyakarta. Retrieved from http://eprints.uny.ac.id/13495/1/HAL JUDULDAFT

ISI.pdf

Direktur Jenderal Pengembangan Destinasi Pariwisata Kementerian Pariwisata dan Ekonomi Kreatif. Buku Pedoman Kelompok Sadar Wisata. 2012. Jakarta

Fadriyani, (2010). Keterlibatan Orang Tua Dan Intervensi Guru Dalam Perkembangan Literasi Anak Usia Dini: Studi Kasus Di TK Bhayangkari Kabupaten Bone Propinsi Sulawesi Selatan. Bandung: Universitas Pendidikan Indonesia

Grilli, G., Tyllianakis, E., Luisetti, T., Ferrini, S., \& Turner, R. K. (2020). Prospective tourist preferences for sustainable tourism development in Small Island Developing States. Tourism Management, 82, 104178.

Hall, C. M. (2019). Constructing sustainable tourism development: The 2030 agenda and the managerial ecology of sustainable tourism. Journal of Sustainable Tourism, 27(7), 1044-1060.

Higgins-Desbiolles, F. (2018). Sustainable tourism: Sustaining tourism or something more? Tourism management perspectives, 25, 157-160.

Badan Pusat Statistik. 2018. Kabupaten Gunungkidul dalam angka tahun 2018

Martínez, J. M. G., Martín, J. M. M., Fernández, J. A. S., \& Mogorrón- 
Guerrero, H. (2019). An analysis of the stability of rural tourism as a desired condition for sustainable tourism. Journal of Business Research, 100, 165-174.

McEwan, C., Mawdsley, E., Banks, G., \& Scheyvens, R. (2017). Enrolling the private sector in community development: Magic bullet or sleight of hand? Development and Change, 48(1),28-53. doi:10.1111/dech.12283

Mihalic, T. (2016). Sustainable-responsible tourism discourse-Towards 'responsustabel'tourism. Journal of Cleaner Production, 111, 461-470.

Nadiasari, N., \& Nurhadi, N. (2019). Pengorganisasian Kelompok Sadar Wisata Melalui Program Desa Wisata di Desa Pujon Kidul. Jurnal Pendidikan Nonformal, $\quad$ 14(2), 94-107. doi:http://dx.doi.org/10.17977/um041v1 4i2p94-107

Nur Indah Ariyani, Argyo Demartoto, Ahmad Zuber. (2015). Habitus pengembangan desa wisata kuwu: studi kasus desa wisata kuwu kecamatan Kradenan Kabupaten Grobogan. Jurnal Analisa Sosiologi, (2): $60-74$

Pan, S. Y., Gao, M., Kim, H., Shah, K. J., Pei, S. L., \& Chiang, P. C. (2018). Advances and challenges in sustainable tourism toward a green economy. Science of the Total Environment, 635, 452-469.

Polat, N., \& Hermans, E. (2016). A model proposed for sustainable accessible tourism (SAT). Tékhne, 14(2), 125-133.

Pramono.S.Novi. (2016). Meliterasikan Generasi. Saat literasi jadi model. Opini. Librarian \& Public Relation Office Supporting Team Universitas Katolik Widya Mandala Surabaya

Ritchie, J.B. \& Crouch, G.I. (2003). The competitive destination: A sustainable tourism perspectiv
Sanches-Pereira, A., Onguglo, B., Pacini, H., Gómez, M. F., Coelho, S. T., \& Muwanga, M. K. (2017). Fostering local sustainable development in Tanzania by enhancing linkages between tourism and small-scale agriculture. Journal of Cleaner Production, 162, 1567-1581.

Schneider, I. (2018). Big data-based capitalism, disruption, and novel regulatory approaches in Europe. In A. R. Saetnan , I. Schneider, \& N. Green (Eds.), The politics and policies of big data: Big data, big brother? Abingdon: Routledge.

Sharpley, R. (2020). Tourism, sustainable development and the theoretical divide: 20 years on. Journal of Sustainable Tourism, 28(11), 1932-1946.

Sullivan, A. and Sheffrin, S.M. (2003) Economics: Principles in Action. Pearson Prentice Hall, Upper Saddle River, 157.

Tang, X. (2017). The historical evolution of China's tourism development policies (1949-2013)-A quantitative research approach. Tourism management, 58, 259-269.

UNESCO. (2005). Development of Information Literacy: Through School

Libraries in Southeast Asia Countries. Bangkok.

UNWTO \& UNDP . (2017). Tourism and the sustainable development goals - Journey to 2030. Madrid: UNWTO.

Wijaya, S., Zulkarnain, Z., \& Sopingi, S. (2018). PROSES BELAJAR KELOMPOK SADAR WISATA (POKDARWIS) DALAM PENGEMBANGAN KAMPOENG EKOWISATA. Jurnal Pendidikan Nonformal, 11(2), 88-96. doi:http://dx.doi.org/10.17977/um041v1 1i2p88-96 